\title{
KREATÍV KISTÉRSÉGEK MAGYARORSZÁGON ${ }^{1}$
}

\author{
(Creative Micro-regions in Hungary)
}

\section{RITTGASSZER IMOLA}

Kulcsszavak:

kreatívosztály tudásalapú gazdaság kistérségek terïleti elemzés

A gazdasági környezetet a globalizáció mellett napjainkban egyéb háttérfolyamatok is befolyásolják, átalakitják, amelyekre, mint térszervezó erökre érdemes és kell is odafigyelni. Manapság a globalizációs folyamatok alakulásából egyértelmüen latszik, hogy az emberi tényezók és az arra épülö tudás válhat a fejlödés jövỏbeli kulcstényezöjêvé. Egy olyan világban élünk, ahol a tudás, az emberi kreativitás és a végeláthatatlan információk feldolgozásának képessége szintén a fejlödés egyik mozgatórugója.

Jelen tanulmány célja annak vizsgálata, hogyan lehet a magyarországi kistérségeket a kreatív osz.tály elhelyezkedése szerint csoportosítani. Kiinduló kérdés, hogy a kistérségek, mint területi egységek alkalmasak-e a kreativ osztály térbeli elhelyezkedésének vizsgálatára? Tovabbi alapkérdések, hogy a kreatív osztály elhelyezkedése milyen kapcsolatban van a jövedelemképzódéssel, valamint az, hogy a kreatív osztály valóban az, urbânus térségekben koncentrálódik-e?

A magyarországi kistérségek elemzésénél Richard Florida kreatív osztállyal foglalkozó vizsgálatából indulunk ki. A magyar kistérségekre kialakitott adatbázist és mutatóit többváltozós statisztikai eljárásokkal vizsgaljuk.

\section{Bevezetés}

A globális versenyben nem a tárgyi javak, hanem egyre inkább a tudás vagy a kapcsolati tỏke váltak kulcsfontosságú tényezővé, a gazdasági fejlödés legfontosabb mozgatórugóivá (Enyedi 2000). A regionális tudományban a tudást, mint a regionális fejlődés meghatározó tényezőjét azonosítják (Lengyel I. 2003; Rechnitzer-Smahó 2005; Varga 2005). A regionális növekedést, fejlődést meghatározó tényezök változását figyelembe véve Magyarországon is azt tapasztalhatjuk, hogy a rendszerváltást követő években azok a térségek emelkedtek ki, ahol a humán tényezők koncentráltan jelen vannak. Manapság a humán tỏke minősége - több elismert tudományos irányzat szerint innovativitása, kreativitása - és a gazdasági fejlödés szoros kapcsolatban áll egymással, továbbá egy térség sikerességét többek között az határozza meg, hogy a rendelkezésre álló kreatív munkaerő mennyire képes innovatív gazdasági teljesítményre (Lengyel I.-Rechnitzer 2004; Varga 2009). A képzett munkaerőn kívül természetesen számos tényezőnek szerepe van egy térség gazdasági teljesítményében, de napjainkban a tudás, az emberi kreativitás és az információk feldolgozásának képessége a fejlődés egyik legfontosabb mozgatórugójảvá vált. Mindezekböl következik, hogy tudásalapú gazdaságfejlesztési stratégiát azon térségekben lehet sikeresen alkalmazni, ahol rendelkezésre áll a megfelelő minőségü humán erőforrás (Lengyel I. 2007). 
A regionális fejlődést a munkaerő minőségére visszavezető irányzatok közül kiemelkedik az amerikai közgazdász-geográfus Richard Florida által kidolgozott elmélet. Florida nem csak a kreatív osztály fogalmát vezette be, hanem az Amerikai Egyesült Államok nagyvárosi régióira a kreatív osztály vizsgálatára alkalmas módszert is kidolgozta (Florida 2000a).

\section{A tudásalapú gazdaság és a kreatív osztály}

A tudásalapú gazdaság legszélesebb körben elfogadott definícióiból kiderül, hogy a tudásalapú gazdaság egy igen komplex fogalom, széles körü tulajdonságokkal bír, amely számos aspektusból megközelíthetö (OECD 1996, 7; 2005, 28; DTI 1998; Leadbeater 1999; Kok 2003; ESRC 2005; Leydesdorff 2006; WBI 2007; HugginsIzushi 2008; Lengyel B.-Leydesdorff 2008). A definíciók között egyetlen egy közös metszet található, ami a tudás teremtésének kiemelkedő szerepét hangsúlyozza. Ebböl is levonható az a következtetés, hogy a tudásalapú gazdaság indikátorokkal való leképezése nem történhet meg néhány kiragadott mutatóval, hanem komplex, többváltozós elemzést kell alkalmazni.

A globális gazdaság tudáshoz kötődő magyarázatai továbbá alapvetően kétféle logika szerint csoportosíthatóak:

1) A „tudásalapú gazdaság”, mint hívószó, mint program inkább gazdaságpolitikai jellegü fogalom. A gazdaságpolitikai közgondolkodás alapvetően a $\mathrm{K}+\mathrm{F}$ képességben látja a tudásalapú gazdaságban való érvényesülés zálogát (Bajmócy 2008; Lengyel B. 2008).

2) A tudásalapú gazdaság másik magyarázata a humán tỏke oldalhoz kapcsolódik, a tudás létrehozásában és terjesztésében játszik kiemelt szerepet (Varga 2009).

A tanulmány tárgyát ez utóbbi, vagyis a tudásalapú gazdaság humántöke oldalának speciális szegmense, a kreatív osztály elhelyezkedésének vizsgálata képezi, és nem foglalkozik a tudásalapú gazdaság gazdaságpolitikai oldalával. Rechnitzer János és Smahó Melinda $(2005,14)$ kiemeli, hogy „, a hazai területi kutatások eddig elhanyagolták a tudásnak, mint a regionális fejlödés új elemének vizsgálatát', így bár ezen a területen az utóbbi idöben jelentős elörelépések történtek - kutatásunkkal ebbe az irányba kívánunk elmozdulni. Természetesen a globális gazdaság tudáshoz kötődő magyarázatainak kétféle logika szerinti csoportosítása nem választható el egymástól, hiszen a humán töke minősége, alapvetően befolyásolja, hogy az adott térségben lehetséges-e tudásalapú gazdaságfejlesztési stratégiát alkalmazni. A tanulmány elemző részében erre majd még röviden visszatérünk.

A tudásalapú gazdaság mibenlétének vizsgálatakor alapvetỏ kérdés, hogy mi mozgatja a tudásalapú gazdaságot? A kérdésre adott egyik elfogadott válasz szerint, amely a tudásalapú gazdaság humán töke szegmense felöl közelíthető, az egyes térségek fejlödési lehetőségeit nagyban meghatározza a térségben fellelhetö humán erőforrás mennyisége és minösége (Rechnitzer-Csizmadia-Grosz 2004). Florida (2002a) 
szerint a 21. században már nem egyszerüen tudásalapú gazdaság, hanem inkább kreativ gazdaság jött létre, amit a humán eröforrás egy speciális részhalmaza, a kreatív osztály mozgat.

\section{Richard Florida alapmodellje}

Florida a gazdasági fejlődést az ún. $3 T$ modellel, azaz a Technológiával, a Tehetséggel és a Toleranciával magyarázza. Ennek lényege, hogy a technológia, mint a gazdasági növekedés egyik - általánosan elfogadott - kulcsa mellett a tehetséget és a toleranciát is a kreatív gazdaság növekedésének előmozdítójaként veszi számba. Florida szerint e három tényezỏ a gazdasági fejlődés három szuikséges, de önmagában nem elégséges feltétele. Florida azt állítja, ha egy régióban megvan ez a három tényező, és együtt is képesek jól müködni, akkor a régió képes lehet fejlődést produkálni, ellenkezỏ esetben azonban lemarad (Florida 2002a):

1) Technológia, az első T: A 3T első eleméről, a technológiáról a neoklasszikus Robert Solow Nobel-díjjal kitüntetett munkájában kimondta, hogy a gazdasági fejlödés fellendítése inkább függ a technológiai haladás mértékének növekedésétöl, mint az addig vizsgált tőkefelhalmozástól vagy piacbővüléstől (Lengyel I.Rechnitzer 2004). Technológia alatt Florida az adott terület gazdaságitechnológiai fejlettségét érti, ami a high-tech iparágak meglétét jelenti. Szerinte szuikséges, de nem elégséges feltétele a high-tech iparágak jelenléte egy térségben, hogy a térség kreatív központtá válhasson és újabb kreatív embereket, valamint vállalatokat tudjon odavonzani, amelyek dinamikus gazdasági növekedést és magasabb foglalkoztatottságot tudnak generálni.

2) Tehetség, a második T: A tehetség, mint második változó a szintén Nobel-díjas Robert Lucas humán tőke szerepét kihangsúlyozó téziseire vezethető vissza. Ezen kulcstényező a rendelkezésre álló humán erőforrás minöségét jelenti. A jól képzett emberek képesek új tudást létrehozni. A már meglévő és új tudásukat hatékonyan, kreatívan képesek alkalmazni, ezáltal értékeket elöállítani. A kreatív munkavégzéshez nem feltétlenül szükséges felsőfokú végzettség, de azért a legtöbb kreatív munkavégző valamilyen felsőfokú diplomával rendelkezik. A kreatív osztály tagjai általában tudás-intenzív iparágakban dolgoznak, nagymértékủ kreatív tökével rendelkeznek, amelyet felhasználnak a munkájuk során éppúgy, mint az élet égyéb területein is. A kreatív osztály elöállításában fontos szerepe van az egyetemeknek, mint katalizátoroknak.

3) Tolerancia, a harmadik $T$ : A Florida-féle 3T modell harmadik, újszerủ tényezöje a modell talán legfontosabb, döntö változója. Maga a tolerancia is többféle módon közelíthető meg, és ez az a tényezö, mely a kreatív osztály életformájának egyik alapköve.

Florida a toleranciát a modellt alapvetően befolyásoló tényezőnek tartja, mert a technológia és a tehetség már eddig is ismert, kulcstényezőként emlegetett változó, amelyeket egy-egy térség gazdasági fejlödésének leírásához korábban is 
felhasználtak. Ezekhez képest a tolerancia elemének szerepeltetése újdonság a modellben. A kreatív osztály tagjainak ugyanis közös jellemzöje az individualizmusra való törekvés. Szeretnek saját maguk urai lenni, és maguk definiálni identitásukat úgy, hogy az kifejezze kreativitásukat. Nyitottak a sokféleségre, mint valami olyan dologra, amely kreatív potenciáljuk kifejtéséhez és megtermékenyüléséhez szükséges (Florida 2004). A kreatív gazdaságban a versenyképes térségek elismerik a kreatív munkaerőt, elfogadják, hogy nem az öltözéke, hanem a szakértelme alapján kell megítélni. „A városok és régiók is veszítenek versenyképességükböl, ha nem reflektálják az új kultúrát" (Florida 2002a, 120). Az elmélet szerint a gazdasági fejlödés a kreatív emberek letelepedési döntéseinek a függvénye. Ezek az emberek pedig olyan helyeket keresnek, amelyek sokszínủek, toleránsak és nyitottak az új ötletekkel szemben. Ez a felismerés teszi szükségessé az új, kreatív gazdaság növekedésének 3T modelljében a tolerancia, mint változó szerepeltetését. A tolerancia ugyanis elősegíti a tehetség érvényesülését, az pedig előmozdítja a gazdasági fejlódést. Florida ezzel azt állítja, hogy a befogadó kulturális, nyitott környezet és a gazdasági fejlödés között szoros kapcsolat mutatható ki (Florida 2005).

Florida egyik munkájában sem ad pontos leírást módszeréről, azt az olvasónak kell kihámoznia és értelmeznie. A módszer mellett az indexek, illetve az azokat leképező indikátorok bemutatásában is hiányosságokat tapasztaltunk. Ennek azonban elönye és hátránya is van. A nem teljesen körülhatárolt módszer elönye, hogy azt tanulmányozva, abból kiindulva, a vizsgált országra, térségre specializálva el lehet készíteni a saját 3T modellt. Hátránya mindenféleképpen az, hogy a módszer és indikátorainak pontról-pontra történő lekövetése lehetetlen.

Florida 3T modelljében egy-egy index meghatározásához legtöbb helyen egy vagy két indikátort használ fel. A saját modell majd tartalmazza azokat az indikátorokat, amelyek relevánsak, azonban a vizsgált térségek specifikumának megfelelően további indikátorok vizsgálatba való bevonása szükséges.

\section{A modell nemzetközi adaptációi}

Florida módszere és indikátorkészlete az amerikai specialitások miatt nagyon nehezen adaptálható Magyarországra, másrészt Florida által elemzett aggregációs szint túl nagy az általunk elemezni kívánt kistérségi szinthez képest. A benchmark példák áttekintésétől azt várjuk, hogy ezen felvetésekre adott válaszainkat megkönnyítik.

A kutatás során áttekintett 10 nemzetközi adaptáció rendkívül fontos tapasztalatokkal járt a módszer magyar kistérségekre történő alkalmazhatóságát illetően. Több szerző is megállapította, hogy az európai területi szintek elemzésénél nem lehetséges a módszer egy az egyben történỏ adaptációja, hiszen Florida $3 T$ modellét alkotó indexekhez tartozó indikátorok többsége elérhetetlen a különbözö országok adatbázisaiból (Andersen-Lorenzen 2005; Hackler-Mayer 2008; Houston 2008; Lengyel B.Ságvári 2008; Zimmerman 2008). Számos áttekintett tanulmány Floridánál jóval több 
mutatót, komplett mutatószámrendszereket használt a valós eredmények elérése érdekében (Andersen-Lorenzen 2005; Mellander-Florida 2007; Clifton 2008; Hara 2008; Lengyel B.-Ságvári 2008) és többváltozós statisztikai elemzéseket alkalmazott a vizsgálat során (Lengyel B.-Ságvári 2008; Sharp-Joslyn 2008 ). A másik lényeges tapasztalat, hogy az elemzésnél elöször érdemes a kiválasztott területi szint teljes körü vizsgálatát elvégezni, majd a levont tanulságok, következtetések után lehetőség szerint szükiteni az elemzésbe vont területeket és azokra egy újabb vizsgálatot elkészíteni (Andersen-Lorenzen 2005; Lengyel B.-Ságvári 2008). Ez a módszer az általunk kiválasztott területi szintre maradéktalanul használható az egyes hazai kistérségek igen különböző fejlettségét és tulajdonságait alapul véve.

A vizsgált nemzetközi munkák mindegyike Richard Florida alapmódszertanára és alapmodellére épült, azonban megállapíthatjuk, hogy kivétel nélkül minden tanulmányban található valami újdonság, ami Florida módszertanának alapos átgondolása után az adott ország és az elemzésül választott terïleti szint sajátosságainak köszönhetỏ. Mindezek után megállapíthatjuk azt, hogy a nemzetközi munkák majdnem azonos fogalomkészlettel, azonos elemzési módszerekkel, illetve hasonló indikátorkészlettel közelítették meg a kreatív osztály térbeli elhelyezkedésének vizsgálatát.

Richard Florida módszertanára épülő nemzetközi adaptációk tapasztalatait csak közvetetten tudjuk alkalmazni az elemzésünk során, hiszen nemzetközi viszonylatban városokat, régiókat, városrégiókat vagy éppen munkaerö-vonzáskörzeteket vizsgáltak a szerzök - kivéve Lengyel és Ságvári -, amelyek az általunk vizsgálni kívánt területi szintnek nem felelnek meg. A nemzetközi tanulmányokból egyedül Andersen és Lorenzen (2005) elemzésében használt területi egységhez, a városrégiókhoz hasonló az elemzésünk alapegységéül választott kistérségi szint.

Természetesen a tanulmányban bemutatni kívánt, általunk kialakított módszer csak egy lehetséges változata annak, hogyan lehet a magyarországi kistérségekre a kreatív osztály térbeli elhelyezkedését és a térségi fejlödést értelmezni, elemezni.

\section{A magyar kistérségek elemzése}

Az áttekintett elemzések többsége városrégió, munkaerő-vonzáskörzet, illetve kistérség szinten vizsgálódott. Az első kettó a régió fogalmak közül a csomóponti régiónak feleltethetó meg (Lengyel I.-Rechnitzer 2004), amely közgazdasági értelemben igen fontos és jól értelmezhetö, azonban statisztikai adatokkal nagyon nehezen leképezhető kategória, mivel a határai nem adhatóak meg pontosan.

Az elemzés alapegységének a nemzetközi gyakorlatnak megfelelően mi is munkaerö-vonzáskörzeteket vagy városrégiókat alkalmaznánk. A hazai statisztikai adatgyüjtésben a munkaerö-vonzáskörzetnek leginkább a kistérség feleltethető meg (Lukovics 2007). 


\section{A felhasznált adatállomány}

Az adatállomány kialakításánál alapvetóen Richard Florida 3T modelljét leképező indikátorokhoz tartozó adatokat gyüjtöttünk össze, illetve nemzetközi és hazai tanulmányokra támaszkodtunk. Fontos megemlíteni, hogy a végleges, az elemzés alapjául szolgáló adatállomány kialakítása többszöri finomitás után nyerte el végsö formáját.

Munkánkat a kistérségi szinten elérhetõ adatok korlátolt száma és az alapmodellben használt, Magyarországon nem gyüjtött adatok hiánya is nehezítette. A 174 kistérségre vonatkozó adatok túlnyomó többsége az Országos Területfejlesztési és Területrendezési Információs Rendszerból (továbbiakban TeIR) származik. Emellett a szabadalmak számát a Magyar Szabadalmi Hivatal „PIPACS” iparjogvédelmi adatbázisából, a köztestuileti tagok számát az MTA Köztestületi adatbázisból gyűjtöttük, míg a $\mathrm{K}+\mathrm{F}$ adatokat a Központi Statisztikai Hivataltól egyéni adatkérés után kaptuk meg.

Az adatbázis elkészítésénél sok szempontot figyelembe vettük, de leginkább arra törekedtuink, hogy a dolgozat elemző részénél a 2008-ban elérhetô legfrissebb adatokat használjuk fel. Az adatbázis 2006-os kistérségi adatokból és a 2001-es népszámlálás adataiból épül fel. Igaz, hogy a 2001-es népszámlálási adatok a 7 évvel ezelötti állapotot mutatják, de ezeket tudtuk csak felhasználni, hiszen ez a legfrissebb olyan teljes körủ adatforrás, amely rendelkezésre áll.

Az ily módon kialakított adatbázis 93 alapadatot ${ }^{2}$ tartalmazott, amelyekböl fajlagos, illetve aránymutatókat képezve állt elö az elemzés alapjául szolgáló adatbázis. A következö lépésben ezeket az adatokat a $3 T$ modell szerint rendeztük, így a Florida-féle Technológia dimenziót 11, a Tehetség dimenziót 26, míg a Tolerancia dimenziót 16 mutató képezte le. Összesen 53 mutatóval kezdtük meg az elemzést. Itt jegyeznénk meg, hogy a különbözỏ dimenziókhoz tartozó mutatószámok aránytalan eloszlása nem jelenti az elemzésben a több mutatóval leképezett dimenzió felülreprezentáltságát. Az egyes dimenziókon belül ugyanis külön-külön rangsorok készülnek, a végső T index pedig ezek súlyozatlan számtani átlagából áll elő, vagyis az, hogy az egyes dimenziók hány indikátorból álltak, a végső $\mathrm{T}$ index kalkulációja során indifferenssé válik.

Az elemzés nem egy az egyben Florida módszertanának és modellének adaptációja, hanem az alapmodell és külföldi alkalmazásainak tanulságai alapján egy megfelelő adatbázissal alátámasztott elemzés, ami az alapmodellhez képest módszertani újdonságokkal is szolgál. Tulajdonképpen a fö ötletet, a gondolati vázat és a módszertani mérföldköveket vesszük át, és azokat az általunk vizsgált területi egység sajátosságaihoz igazítjuk. A módszertani újdonságok alatt egyrészt azt értjük, hogy sokkal több változót használunk fel a modell kialakításához, mint Florida és a többi szerzö, továbbá az elemzést a magyar sajátosságokhoz alakítjuk. 


\section{Az elemzés módszertana}

Az adatbázis 53 kiinduló mutatójának standardizálása után Florida modelljét követve létre kívánjuk hozni mindhárom $\mathrm{T}$ esetén a kistérségek rangsorát, majd ezek alapján a végső rangsort. Az áttekintett elemzések alapján nyilvánvalóvá vált, hogy a teljes térszerkezet minden egyes térsége nem tekinthetö a kreatív osztály megjelenési helyének, így többen az elemzés oly módon történő szofisztikálására vállalkoztak, hogy bizonyos kritériumok szerint leválasztott térségekkel, mint alapsokasággal végezték tovább az elemzést.

\section{1. ÁBRA}

Az elemzés módszertanának logikai szerkezete

(The Logical System of the Methodology of the Analysis)

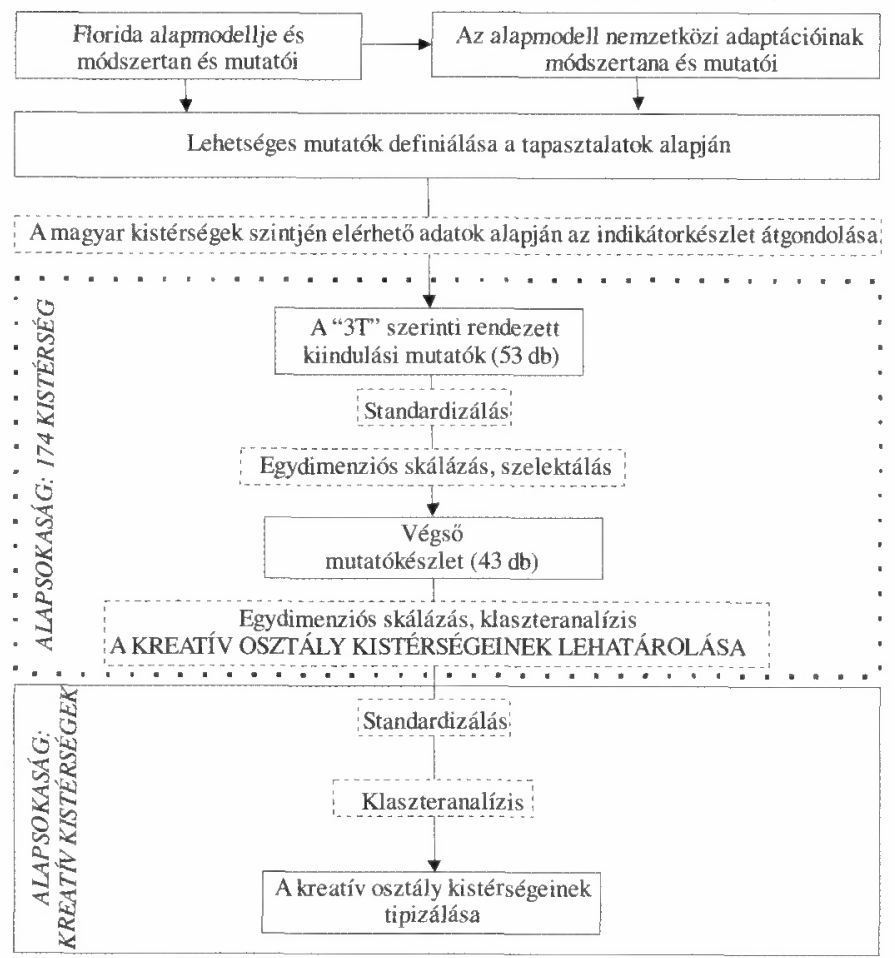

Forrás: Saját szerkesztés.

Azon elözetes elképzelés, miszerint az elemzés alapsokaságának számító 174 kistérséget azok vizsgálata után leszúkítsük azokra a kistérségekre, ahol nagyobb valószínủséggel lelhető fel a kreatív osztály, Florida munkáiból is következik. Florida szerint elméletileg sincs értelme markánsan eltéró fejlettségú térségeket együtt vizsgálni, így célszerü leválasztani és további elemzések alá vonni azon térségeket, amelyekben a kreativ osztály koncentráltabban jelen van, mint a többi térségben 
(Florida 2002b). A leszükítésre alkalmas módszer egy rangsor készítése egydimenziós skálázás segítségével, melynek eredményeként a rangsor elején a legjobban, a rangsor végén pedig a gyengébben teljesítô kistérségek állnak. A kreatív osztály legföbb előfordulási térségei az egydimenziós skálázás alapján azonban csak igen szubjektív módon választhatók ki. Annak érdekében, hogy a leválasztást minél objektívebb módon végezzük el, klaszteranalízist alkalmazunk.

Ezt követően reményeink szerint a 174 kistérségböl kiválasztható azon kistérségeknek a köre, amelyekben a kreatív osztály már nagy valószínüséggel elöfordul, így az elemzés további részében ezen $n$ darab kistérséget fogjuk alapsokaságnak tekinteni. A kreatív osztály elöfordulási helyeként definiált $n$ darab kistérséget az elemzés során felhasznált 53 mutató alapján tovább differenciáljuk klaszteranalízis segítségével (1. ábra). Végül korrelációszámítás segítségével finomítjuk a kapott eredményeket.

\section{Végső mutatókészlet}

Ahogy a módszertani részben leírtuk, elöször egydimenziós skálázást futtattunk le ${ }^{3}$ minden T dimenzióra, melynek eredményeként minden egyes kistérség a Technológia, Tehetség és Tolerancia dimenzió mentén egy-egy koordinátát kapott, amelyek alapján rangsorolni lehetett a kistérségeket. Ezen vizsgálat során a Technológia és a Tehetség dimenziót leképező mutatóknál minden változó benne maradt megfelelő S-stress értékkel, azonban a Tolerancia dimenziónál szelektálást kellett végezni a mutatók között. Ezen mutatók matematikai-statisztikai módszerekkel történő szelektálása után a végsö adatbázis 11 technológiát leképezö, 25 tehetséget leképezö és 6 toleranciát leképezö, vagyis összesen 43 mutatóból áll (1. táblázat).

A 3 dimenzió együttese alapján kialakított végső rangszám a három egydimenziós skálázás rangszámainak átlagolásával állt elö.

\section{TÁBLÁZAT \\ A végsõ mutatókészlet \\ (The Final Set of Indicators)}

\begin{tabular}{l} 
Mutató megnevezése \\
\hline 1. A 10000 lakosra jutó szabadalmak száma a kistérségben 2000-2006 közötti időszakban (db) \\
2. K+F helyek száma 10000 lakosra, 2006 (db) \\
3. $\mathrm{K}+\mathrm{F}$ helyek beruházásai 1000 lakosra, $2006(\mathrm{eFt})$ \\
4. K+F helyek költségei 1000 lakosra, $2006(\mathrm{Ft})$ \\
5. $\mathrm{K}+\mathrm{F}$ helyek ráfordításai 1000 lakosra, 2006 (eFt) \\
6. K+F helyek tényleges összlétszáma 1000 lakosra, 2006 (fö) \\
7. K+F helyek tudományos kutatóinak tényleges létszámadata 1000 lakosra, 2006 (fö) \\
8. 10000 lakosra jutó MTA köztestuletí tagok száma, 2006 (fó) \\
9. Számítógépek száma a közoktatási intézményekben 1000 lakosra, 2006 (db) \\
10. Internettel ellátott feladatellátási helyek száma a közoktatási intézményekben 10000 la- \\
kosra, 2006 (db) \\
11. ISDN vonalak száma 1000 lakosra, 2006 (db)
\end{tabular}


12. Rendszeres mủvelődési foglalkozások száma 1000 lakosra, 2006 (fö)

13. Rendszeres müvelödési formákban résztvevők száma 1000 lakosra, 2006 (fö)

14. Felsőoktatásban részt vevö hallgatók száma minden tagozaton az intézmény székhelye szerint 1000 lakosra, 2006 (fö)

15. Felsőoktatási intézményekben dolgozó oktatók száma az intézmény székhelye szerint 10000 lakosra, 2006 (fö)

16. Állandó színházak látogatóinak száma 1000 lakosra, 2006 (fö)

17. Regisztrált vállalkozások száma az egészségügyi, szociális ellátás nemzetgazdasági ágban 10000 lakosra, $2006(\mathrm{db})$

18. Regisztrált vállalkozások száma az oktatás nemzetgazdasági ágban 10000 lakosra, $2006(\mathrm{db})$

19. Regisztrált vállalkozások száma a pénzügyi közvetítés nemzetgazdasági ágban 10000 lakosra, $2006(\mathrm{db})$

20. A munkahelyi, felsőoktatási és egyéb könyvtárak beiratkozott olvasóinak száma 1000 lakosra, 2006 (fö)

21. Kulturális rendezvények száma 1000 lakosra, 2006 (db)

22. Kulturális rendezvényeken résztvevök száma 1000 lakosra, 2006 (fö)

23. Múzeumi látogatók száma 1000 lakosra, 2006 (fö)

24. Egyéb szellemi foglalkozásúak 1000 lakosra jutó száma, 2001 (fó)

25. Szolgáltatási szektorban dolgozók száma 1000 lakosra, 2001 (fö)

26. Szolgáltatási jellegü ágazatokban dolgozók száma 1000 lakosra, 2001 (fö)

27. Vezetô, értelmiségi foglalkozásúak száma 1000 lakosra, 2001 (fö)

28. Egyetemi, föiskolai végzettségüek száma 1000 lakosra, 2001 (fö)

29. A pénzügyi tevékenységben foglalkoztatottak száma 1000 lakosra, 2001 (fö)

30. Az egészségügyi, szociális ellátásban foglalkoztatottak száma 1000 lakosra, 2001 (fö)

31. Az ingatlanügyek, gazdasági szolgáltatásban foglalkoztatottak száma 1000 lakosra, 2001 (fö)

32. Az oktatásban foglalkoztatottak száma 1000 lakosra, 2001 (fó)

33. A szolgáltatási foglalkozású foglalkoztatottak száma 1000 lakosra, 2001 (fö)

34. A vezetô, értelmiségi foglalkozású foglalkoztatottak száma 1000 lakosra, 2001 (fö)

35. Az egyéb szellemi foglalkozású foglalkoztatottak száma 1000 lakosra, 2001 (fő)

36. Az 1 lakosra jutó szellemi alkotások jövedelme, $2006(\mathrm{eFt})$

37. Szakorvosok száma 1000 lakosra, 2006 (fó)

38. Odavándorlások száma 1000 lakosra, 2006 (fő)

39. Az eltartott férfiak száma 1000 lakosra, 2001 (fö)

40. A 15 éves és idősebb népességböl a nötlenek, hajadonok száma 1000 lakosra, 2001 (fő)

41. A 15 éves és idősebb népességből az elváltak száma 1000 lakosra, 2001 (fó)

42. 1000 lakosra jutó kisebbségiek száma, 2001 (fö)

43. Élettársi kapcsolaton alapuló családok száma 1000 lakosra, 2001 (db)

Forrás: Saját szerkesztés.

\section{A kreativ kistérségek lehatárolása}

Az egydimenziós skálázás segítségével, amint erre már kitértünk, nem tudjuk egyértelmúen meghatározni a kreatív osztály legvalószínủbb előfordulási helyének tekintett kistérségeket. Nem lehet ugyanis önkényesen meghúzni a rangsor valamelyik kistérsége után a határvonalat. Annak érdekében, hogy el tudjuk határolni egymástól a kreatív és a gyengébben prosperáló kistérségeket, klaszteranalízist érdemes alkalmazni.

Az elemzésnél a hierarchikus klaszterezést választottuk, mert nem volt semmiféle elözetes iránymutatás a létrehozandó klaszterek számára vonatkozóan. A hierarchikus klaszterezési eljárás felépitési táblázata alapján négy klasztert sikeruilt azonosítani (2. ábra). 


\section{2. ÁBRA}

A 174 kistérség tipizálása

(Typology of the 174 Micro-regions)

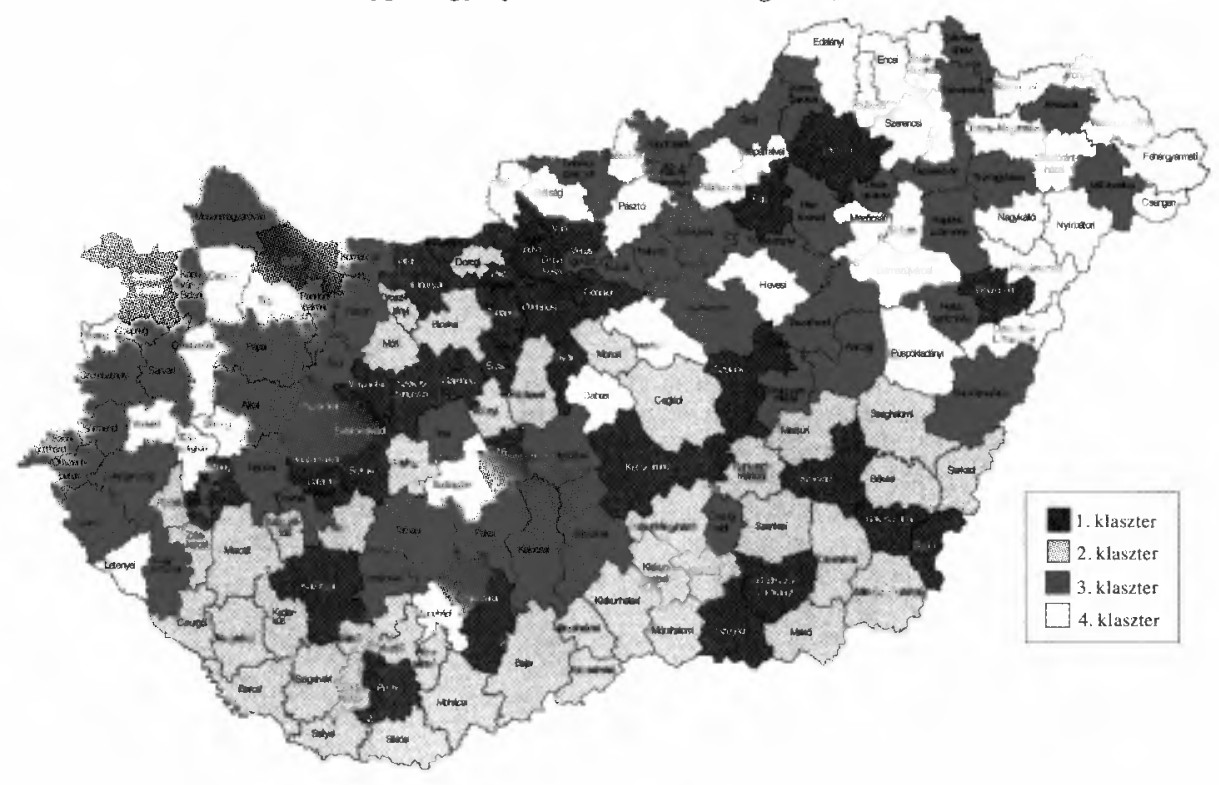

Forrás: Saját szerkesztés.

Az elsö klaszterbe azok a kistérségek kerültek, amelyek mind a technológia, mind a tehetség, mind a tolerancia szempontjából a legkiemelkedöbbek. A második, a harmadik, és a negyedik klaszter olyan kistérségekból épül fel, amelyek legalább az egyik $T$ dimenzió szerint az átlagnál alacsonyabb értéket vesznek fel, így ezen kistérségeket - mint nem kreatív kistérségeket - az elemezés további részéböl elhagyjuk. A továbbiakban tehát kizárólag azon kistérségeket elemezzük tovább, amelyek az első klasztert alkotják.

\section{A kreatív kistérségek tipizálása}

Az új, vizsgálandó alapsokaság az 1. klaszterbe tartozó 38 kistérség. Az új alapsokaság elemzésére felhasznált mutatók köre megegyezik a 174 kistérség elemzésére használt mutatókéval, így a 38 kistérséget 43 mutató segítségével vizsgáljuk.

A 38 kistérséghez tartozó mutatók újbóli standardizálása után klaszteranalízis segítségével további csoportokat hozzunk létre, amelyek elemzésébỏl remélhetöen tovább tudunk differenciálni, illetve pontosítani tudjuk a kreatív osztály elhelyezkedését Magyarországon.

Mivel a létrehozandó klaszterek száma - a 174 kistérségre lefolytatott elemzéshez hasonlóan - ezúttal sem volt elöre meghatározható, így ismét hierarchikus klaszterezési eljárást futtattunk. A klaszterek összevonási táblázatából kiolvasható, 
hogy ezúttal is 4 klaszter lehatárolása indokolt. Az 1. klaszter 5 kistérséget, a 2. klaszter 5 kistérséget, a 3. klaszter 23 kistérséget, míg a 4. klaszter 5 kistérséget foglal magában (2. táblázat).

\section{TÁBLÁZAT}

A kreatív kistérségek típusai

(Types of the Creative Micro-regions)

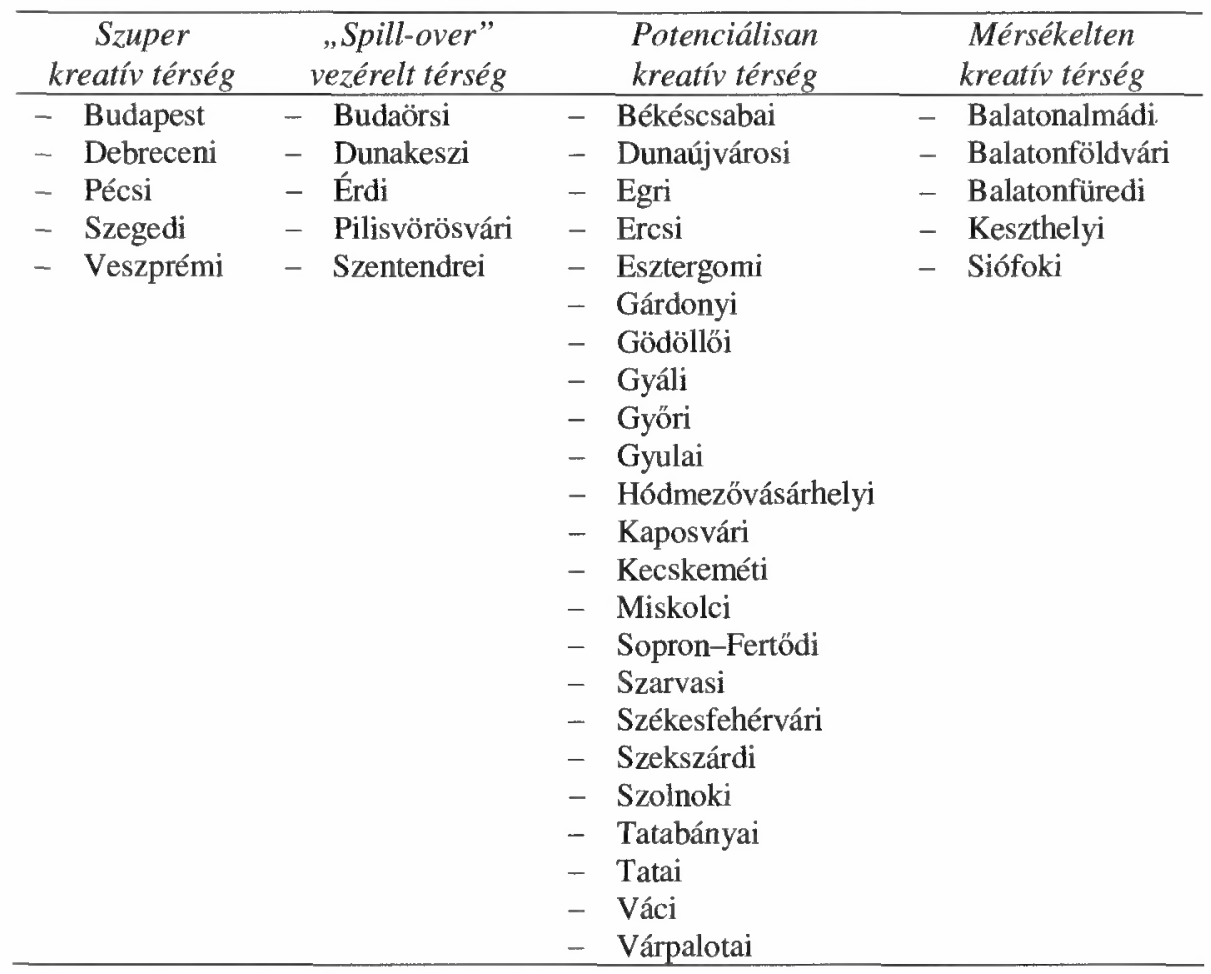

Forrás: Saját szerkesztés.

\section{TÁBLÁZAT}

A változók klaszterenként felvett értékeinek átlagos nagysága a $3 T$ szerint rendezve (The Typology of the 38 Creative Micro-regions)

\begin{tabular}{lccc}
\hline \multicolumn{1}{c}{ Klaszter } & Technológia $(T 1)$ & Tehetség (T2) & Tolerancia (T3) \\
\hline $\begin{array}{l}\text { Szuper } \\
\text { kreatív térség }\end{array}$ & magas & magas & magas \\
$\begin{array}{l}\text { „Spill-over” } \\
\text { vezérelt térség }\end{array}$ & relatíve alacsony & relatíve magas & relatíve magas \\
$\begin{array}{l}\text { Potenciálisan } \\
\text { kreatív térség }\end{array}$ & relatíve magas & közepes & közepes \\
$\begin{array}{l}\text { Mérsékelten } \\
\text { kreatív térség }\end{array}$ & közepes & relatíve alacsony & relatíve alacsony \\
\hline
\end{tabular}

Forrás: Saját szerkesztés. 
Nagy hangsúlyt fektettünk arra, hogy az egyes klaszterek legfőbb tulajdonságait megtaláljuk, ezért a klaszteranalízis outputjában levő táblázatok minden egyes klaszterhez tartozó értékeinek alapos, egyenkénti vizsgálata után megkíséreltiuk elnevezni a négy klasztert úgy, hogy az elnevezés tükrözze az egyes klaszterbe tartozó kistérségek viszonyát a $3 T$ dimenzióhoz (3, táblázat).

A klaszteranalízis lefuttatása után kiemelten fontos a kapott eredmények értelmezéséhez, hogy meghatározzuk az egyes klaszterek legfontosabb tulajdonságait aszerint, hogy az egyes kistérségek klaszterekbe rendezése mely ismérvek alapján történt. Technikailag mindez úgy valósítható meg, hogy az SPSS egyik outputjában listázza minden egyes változónak az adott klaszterben felvett átlagos értékét. Ezen értékek elemzése után egyértelmủen meghatározható, hogy az egyes klaszterekbe milyen tulajdonságokkal rendelkező kistérségek kerültek, így kialakíthatóvá vált a kreatív magyar kistérségek négy alaptípusa (3. ábra):

1) Szuper kreatív térség ${ }^{4}$ : az 5 kistérség, ahol mindhárom $\mathbf{T}$ dimenzió szerinti változók a legmagasabb értéket veszik fel. A Budapesti, Debreceni, Pécsi, Szegedi és Veszprémi kistérség a Technológia, a Tehetség és a Tolerancia szempontjából kiemelkednek. Ezen kistérségek állnak az egydimenziós skálázás eredményeként megkapott végső rangsor előkelő első 5 helyén is. Mindhárom $\mathrm{T}$ változói átlagosan magasabb értéket mutatnak ebben a klaszterben, mint a többi háromban.

2) „Spill-over” vezérelt térség: a 3T szerint csoportosított változók közül azok mutatnak relatíve magas értéket, amelyek a Tolerancia és a Tehetség körébe tartoznak, míg a Technológia változói relatíve alacsony értékkel bírnak. Ebbe a klaszterbe Budapest agglomerációs gyürüjébe tartozó kistérségek tartoznak, amelyek északról, északnyugatról, nyugatról és délnyugatról határolják. Napjaink társadalmi-gazdasági folyamatait vizsgálva azt találjuk, hogy a Budapesten jelentkező urbanizációs hátrányokra adott válaszként egyrészt a fóvárosban koncentrálódó gazdasági és politikai elit egyre inkább az agglomerációba költözik ki, onnan jár be Budapestre dolgozni, másrészt pedig a vállalatok egyre nagyobb része választ telephelyet a föváros helyett az ahhoz nagyon közel levő, de jóval élhetőbb agglomerációban található településeken. Ezen klaszter kistérségeinek kreativitása nagyban tulajdonítható a Budapesten képződő tudás túlcsordulásának (spill-over).

3) Potenciálisan kreativ térség: ezen kistérségeknek a Technológia dimenzióhoz tartozó változói relatíve magas értéket képviselnek, továbbá a Tehetség változói közepesen magas, illetve a Tolerancia dimenzió szerint is a változók közepesen magas értéket mutatnak. A Technológia változóinak magas értéke annak köszönhetö, hogy az ebbe a klaszterbe tartozó kistérségek 90\%-ában jelen van valamilyen felsőoktatási intézmény székhelye vagy kihelyezett tagozata. Ha az egydimenziós skálázás végső rangsorát nézzük, akkor a Potenciális kreatív klaszterbe tartozó kistérségek a rangszámaik alapján a rangsor első harmadába tartoznak. 
4) Mérsékelten kreatív térség: olyan kistérségeket reprezentál, amelyek a 3T dimenzió szerint csoportosított változók közül közepes értéket értek el a Technológia dimenzióban, míg a Tolerancia és a Tehetség dimenziókhoz tartozó változók relatíve alacsony értéket mutatnak. A Mérsékelten kreatív térség klaszterébe csupán 5 kistérség tartozik, azonban ezek földrajzilag közel helyezkednek el egymáshoz a Balaton közelében.

\section{Az elemzés néhány további következtetése}

A kapott eredmények alapján néhány további statisztikai vizsgálatot végeztünk el, amelyeket a következö két vezérfonal mentén lehet elkülöníteni:

1) A kreatív osztály és a jövedelemképződés közötti kapcsolat vizsgálatával az a cél, hogy megállapítsuk, vajon a kreatív osztály, illetve a kreatív osztály számára fontos feltételek esetleges fejlesztése várhatóan együutt jár-e az adott térségek jövedelmi szintjének várható növekedésével, ceteris paribus.

2) A kreatív osztály és az urbanizáltság kapcsolatának vizsgálatával az a célunk, hogy feltárjuk, vajon a tudásalapú (vagy Florida szerint kreatív) gazdaság motorjaként definiált kreatív osztály fellelhető-e egyáltalán a rurális térségekben. Másképpen fogalmazva: rurális térségekben érdemes-e ezen vizsgálati szempont szerint a kreatív osztály, illetve a kreatív osztály számára fontos feltételek fejlesztésére stratégiákat kidolgozni.

Fontos kérdés, hogy a kreatív osztály milyen kapcsolatban van a jövedelemképzödéssel. A GDP helyett, mivel kistérségre nem áll rendelkezésre, sokan alkalmazzák kistérségi szintü jövedelem mérésére az egy före jutó bruttó hozzáadott érték (GVA) mutatót. Ez azonban félrevezetö lehet, hiszen a TeIR-ben elérhetô bruttó hozzáadott érték néven szereplő mutató a társaságiadó-statisztikából nyerhető székhely szerinti adat, vagyis kizárólag azon adóalanyok bruttó hozzáadott értékét jelenti, amelyek az adott évben társasági adóbevallást készítettek. Ez pedig nem azonos a teljes bruttó hozzáadott értékkel. Mindebből az következik, hogy ezen mutató alkalmazását elvetettük, helyette a könnyen elérhetỏ és jól definiált egy före jutó személyi jövedelemadó alapját képező jövedelem mutatóval fejeztük ki a kistérségi jövedelmet.

A vizsgált két mennyiség között pozitív irányú erős kapcsolat mutatkozik $(r=0,76)$, ami azt jelenti, hogy a kreatív osztály Magyarországon is kimutathatóan a jövedelemtermelésben élen járó térségekben koncentrálódik. Ebből az következik, hogy a kreatív osztály bővülése, illetve a számukra fontos feltételek esetleges fejlesztése várhatóan együtt jár az adott térségek jövedelmi szintjének növekedésével. Ezen megállapítást tovább lehet finomítani akkor, ha azt is meg tudjuk mondani, hogy a 3T közül mely tényező egységnyi változása eredményezi a legnagyobb mértékủ változást a térségi jövedelemben. Erre a kérdésre többváltozós regressziószámítás elvégzésével lehet választ kapni. Ebben a modellben eredményváltozó az egy lakosra jutó személyi jövedelemadó alapját képező jövedelem, a három magyarázó változó pedig a Technológia, a Tehetség és a Tolerancia dimenzió. 


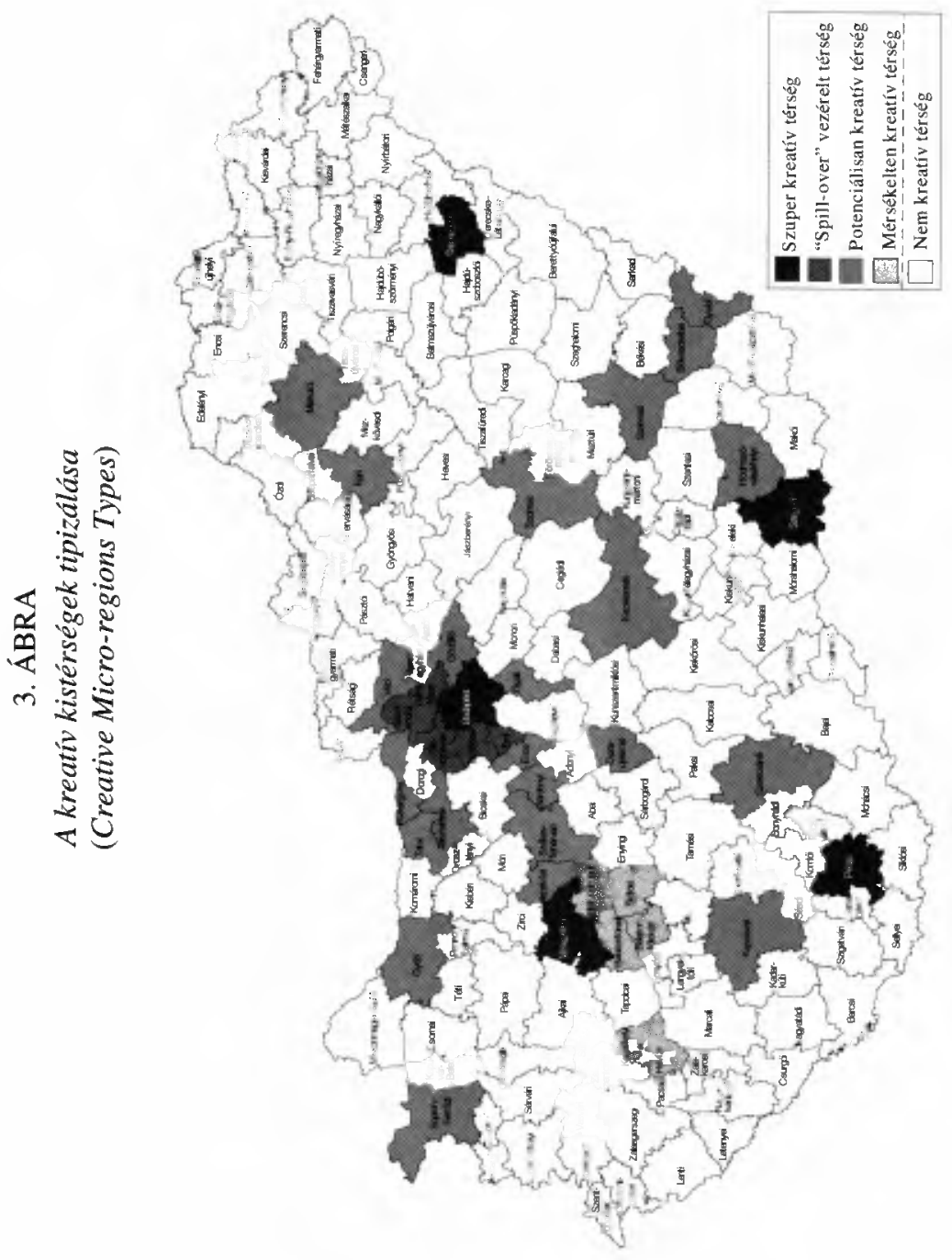

岕 
A kapott regressziós egyenlet:

$\hat{y}_{i}=350256,8+184,04 T_{1}+2131,06 T_{2}+66,13 T_{3}$

ahol:

$T_{I}$ : Technológia dimenzió koordinátái az egydimenziós skálázás alapján

$T_{2}$ : Tehetség dimenzió koordinátái az egydimenziós skálázás alapján

$T_{3}$ : Tolerancia dimenzió koordinátái az egydimenziós skálázás alapján

A paraméterek értelmezéséböl látható, hogy a jövedelem a Tehetség mutatóinak változására a legérzékenyebb, és a Tolerancia mutatók változására a legkevésbé érzékeny. Ez azt jelentheti, hogy ezen modell szerint egy térségben a Tehetség dimenzióhoz tartozó mutatók befolyásolásával az adott térség jövedelmi szintje várhatóan megnő.

A kreatív osztály és az urbanizáltság kapcsolatának számszerüsítéséhez Lukovics Miklós módszertanát alkalmaztuk, amely négy mutató alapján hoz létre urbánusrurális indexet (Lukovics 2008):

1) A kistérségközpont lakosságának száma a vizsgált év végén érje el az 50000 föt.

2) A 120 feletti népsúrúségủ településeken lakók aránya a vizsgált kistérségben legyen legalább $75 \%$.

3) A térségközpont lakosságának aránya a kistérség lakosságában ne legyen kisebb, mint $75 \%$.

4) A kistérségben felsőoktatási intézmény müködik.

Ezen módszer alkalmazásának eredményeként megállapítható, hogy az urbanizáltság és a 174 kistérségre kiszámított végső rangszámok között erős a korrelációs kapcsolat $(r=0,75)$, ami azt jelenti, hogy a kreatív osztály Magyarországon is az urbánus térségekben koncentrálódik. Ebböl következik, hogy a modell szerint a rurális térségekben nem lehet reálisan tudásalapú gazdaságfejlesztést végezni, mert ezen térségek nem rendelkeznek megfelelő feltételekkel. Továbbá azt a következtetést is levonhatjuk, hogy a rurális térségekben a kreatív osztály számára fontos feltételek esetleges fejlesztése várhatóan nem jár együtt az adott térségek jövedelmi szintjének várható növekedésével.

\section{Összegzés}

A tanulmány arra az alapkérdésre kereste a választ, hogyan lehet a magyarországi kistérségeket a kreatív osztály elhelyezkedése szerint csoportosítani. Olyan további kérdéseket boncolgatott, hogy a kreatív osztály elhelyezkedése milyen kapcsolatban van a jövedelemképződéssel, illetve, a kreatív osztály valóban az urbánus térségekben koncentrálódik-e.

A vizsgálat alapján az első megállapítás, hogy a kreatív osztály nem térképezhetö fel egy-két kiragadott mutatóval, az elemzéshez komplex mutatószámrendszert kell alkalmazni. A tudásalapú gazdaság fogalma annyira bonyolult és komplex, hogy az 
ezen alapuló, ebből kiinduló elemzések mutatókészleteinek is komplexnek kell lenni, annak érdekében, hogy az elemzésböl levonható eredmények korrektek lehessenek.

A nemzetközi tanulmányok és saját vizsgálatunk alapján megállapitható, hogy a 174 kistérségben nincs meg mindenhol a kreatív osztály „kritikus tömege”, emiatt szükséges az úgynevezett kreativ kistérségek elkülönített vizsgálata, tipizálása. A Technológia, a Tehetség, a Tolerancia változóinak egydimenziós skálázással történő vizsgálata és a klaszteranalízis elvégzése után létrejött négy csoport alapján egyértelmủen leválaszthatóvá váltak azon kistérségek, amelyeket kreatîv kistérségként definiálhatunk. Ezen leválasztott, 38 kreatív kistérség mind a három dimenzióban a legkiemelkedöbbek.

Az elemzés eredményeként a 38 kreativ kistérség a Technológia, a Tehetség és a Tolerancia klaszterenként felvett értékeinek átlagos nagysága szerint, illetve ezen tulajdonságok értékelése után négy csoportot alkotnak; melyek a Szuper kreatív térség, „Spill-over" vezérelt térség, Potenciálisan kreatív térség, valamint a Mérsékelten kreativ térség elnevezést kapták. A megyei jogú várost is magában foglaló kistérségek öt kivételével (a Nagykanizsai, a Nyíregyházi, a Salgótarjáni, a Szombathelyi és a Zalaegerszegi) kreatív kistérségek. Ezen öt kistérséget a technológia, tehetség és tolerancia dimenziók együittese alapján a nem kreatív térségek közé lehet sorolni.

Továbbá megállapíthatjuk, hogy a kreativ osztály jelenléte jelentôs hatást gyakorol a térség jövedelemtermelésére. A korrelációszámítás a két vizsgált változó között pozitív irányú és szoros kapcsolatot mutatott ki, vagyis a kreatív osztály Magyarországon is a jövedelemtermelésben élen járó térségekben koncentrálódik. Továbbá ebböl az következik, hogy a kreatív osztály bővülése és a számukra fontos feltételek esetleges fejlesztése várhatóan együtt jár az adott térségek jövedelmi szintjének növekedésével. A regressziószámítás elvégzésével lehet választ kapni arra, hogy mely tényezö egységnyi változása eredményezi a legnagyobb mértékủ változást a térségi jövedelemben. Az elemzés paramétereinek vizsgálata után megállapítható, hogy a Tehetség dimenzióhoz tartozó mutatókat befolyásoló tényezök fejlesztésével lehetne az adott térség jövedelmi szintjét leginkább növelni.

Annak vizsgálata, hogy a kreatív osztály valóban az urbánus térségekben koncentrálódik-e, korrelációszámítással, valamint az urbánus-rurális index kiszámításával történt. Az urbanizáltság és a 174 kistérségre kiszámított végső rangszámok közötti erós korrelációs kapcsolat $(r=0,75)$ azt jelenti, hogy a kreatív osztály Magyarországon is az urbánus térségekben koncentrálódik, vagyis a kritikus tömeg megléte szükséges, de nem elégséges feltétele a kreativ osztály jelenlétének. A kreatív osztály elhelyezkedése és a térség jövedelemtermelésére gyakorolt hatásának együttes eredményeként megállapítható, hogy a rurális térségekben a kreatív osztály számára fontos feltételek esetleges fejlesztése várhatóan nem jár együtt az adott térségek jövedelmi szintjének növekedésével. 


\section{Jegyzetek}

${ }^{1}$ Jelen tanulmány a XXIX. Országos Tudományos Diákköri Konferencia Közgazdaságtudományi Szekciójának „Regionális gazdaságtan II” tagozatán I. díjat nyert azonos címü pályamú átdolgozásával, aktualizálásával, a vitában elhangzottak figyelembevételével született.

${ }^{2}$ Beleértve a végső $T$ index korreláció számításához használt adatokat is.

${ }^{3}$ Elemzéseinkhez az SPSS 13.0 verzióját használtuk.

${ }^{4}$ A szuper kreatív szóösszetétel Florida munkáiból következik. Továbbá itt jegyezzük meg, hogy az ebbe a klaszterbe tartozó kistérségek csoportját fejlett országokkal való összehasonlításnál nem lehetne szuper kreatív térségnek nevezni.

\section{Irodalom}

Andersen, K.V.-Lorenzen, M. (2005) The geography of the Danish Creative Class. A Mapping and Analysis. Copenhagen Business School, Frederiksberg.

Bajmócy Z. (2008) A regionális innovációs képesség értelmezése és számbavétele a tanulás-alapú gazdaságban. - Lengyel I.-Lukovics M. (szerk.) Kérdójelek a régiók gazdasági fejlödésében. JATEPress, Szeged, 26-46. o.

Clifton, N. (2008) The „creative class" in the UK: an initial analysis. - Geografiska Annaler Series B:

Human Geography. 1.63-82. o.

DTI (1998) Competitiveness White Paper. Department of Trade and Industry, London.

Enyedi Gy. (2000) Globalizáció és magyar területi fejlódés. - Tér és Társadalom. 1. 1-10. o.

ESRC (2005) ESRC Strategic Plan 2005-2010. Swindon.

Florida, R. (2002a) The rise of the creative class. Basic Books, New York.

Florida, R. (2002b) The economic geography of talent. - Annals of the Association of American Geographers. 92. 743-755. 0.

Florida, R. (2004) Cities and the creative class. Routledge, New York.

Florida, R. (2005) The Flight of the Creative Class: The New Global Competition for Talent. HarperCollins, New York.

Hackler, D.-Mayer, H. (2008) Diversity, entrepreneurship, and the urban environment. - Journal of Urban Affairs. 3. 273-307. o.

Hara, I. (2008) A Study of Regional Creative Development and Policy. Paper presented at the "Culture, Cohesion and Competitiveness: Regional Perspectives" 48th Congress of the European Regional Science Association, Liverpool.

Houston, D. (2008) Will attracting the ,creative class" boost economic growth in old industrial regions? A case study of Scotland. - Human Geography. 2. 133-149. o.

Huggins, R.-Izushi, H. (2008) Benchmarking the knowledge competitiveness of the globe's highperforming regions. A review of the World Knowledge Competitiveness Index. - International Business Journal. 1-2. 70-86. o.

Kok, W. (2003) Enlarging the European Union. Achievements and Challenges. Report of Wim Kok to the European Commission. European University Institute Robert Schuman Centre for Advanced Studies, Florence.

KSH (2007) Terilleti Statisztikai Evkönyv 2006. Központi Statisztikai Hivatal, Budapest.

Leadbeater, C. (1999) New measures for the New Economy Report. Demos, London.

Lengyel B. (2008) Tudásteremtés és ko-evolúció: az egyetem-gazdaság-kormányzat kapcsolatok globális és lokális vetületei. - Lengyel I.-Lukovics M. (szerk.) Kérdöjelek a régiók gazdasági fejlödésében. JATEPress, Szeged. 47-61. o.

Lengyel B.-Leydesdorff, L. (2008) A magyar gazdaság tudásalapú szervezödésének mérése: az innovációs rendszerek szinergiainak térbelisége. - Közgazdasági Szemle. Június. 522-547. o.

Lengyel B.-Ságvári B. (2008) A kreatív munkaerö feltérképezése Magyarországon. A „Tehetség, Technológia, Tolerancia, a kreatív gazdaság lehetôségei Magyarországon." Kézirat. Demos, Budapest.

Lengyel I. (2003) Verseny és terilleti fejlödés: térségek versenyképessége Magyarországon. JATEPress, Szeged. 
Lengyel I. (2007) Fejlesztési pólusok, mint a tudásalapú gazdaság kapuvárosai, - Magyar Tudomány. 6. 749-758. o.

Lengyel I.-Rechnitzer J. (2004) Regionális gazdaságtan. Dialóg Campus, Budapest-Pécs.

Leydesdorff, L. (2006) The Knowledge-Based Economy: Modeled, Measured, Simulated. Universal Publishers, Boca Rota, Florida.

Lukovics M. (2007) A lokális térségek versenyképességének elemzése. Doktori értekezés. Szegedi Tudományegyetem Gazdaságtudományi Kar, Szeged.

Lukovics M. (2008) Térségek versenyképességének mérése. JATEPress, Szeged.

Mellander, C.-Florida, R. (2007) The Creative Class or Human Capital? Explaining regional development in Sweden. CESIS, Stockholm.

OECD (1996) The Knowledge-Based Economy. Science, Technology and Industry. Outlook 1996. Organisation for Economic Co-operation and Development, Paris.

OECD (2005) Oslo Manual. Guidelines for Collecting and Interpreting Innovation Data. Third edition. Organisation for Economic Co-operation and Development, Paris.

Rechnitzer J.-Csizmadia Z.-Grosz A. (2004) A magyar városhálózat tudásalapú megújítóképessége az ezredfordulón. - Tér és Társadalom. 2. 117-156. o.

Rechnitzer J.-Smahó M. (2005) A humán eröforrások sajátosságai az átmenetben. MTA Közgazdaságtudományi Intézet, Budapest.

Sharp, E.-Joslyn, M. (2008) Culture, Segregation, and Tolerance in Urban America. - Social Science Quarterly. 3. 573-591. o.

TeIR (2008) Országos Terïletfejlesztési és Területrendezési Információs Rendszer. VÁTI, Budapest.

Varga A. (2005) Agglomeráció, technológiai haladás és gazdasági növekedés: A $K+F$ térszerkezet makrogazdasági hatásainak vizsgálata. MTA Doktori Értekezés, Pécs.

Varga A. (2009) Térszerkezet és gazdasági növekedés. Akadémiai Kiadó, Budapest.

WBI (2007) Building knowledge economies: advanced strategies for development. World Bank, Washington, D.C.

Zimmerman, J. (2008) From brew town to cool town: Neoliberalism and the creative city development strategy in Milwaukee. - Cities. 4. 230-242. o.

\section{CREATIVE MICRO-REGIONS IN HUNGARY}

\section{IMOLA RITTGASSZER}

Today the economic environment is influenced and transformed by other background pro-cesses besides globalisation, which worth being and have to be paid attention to as area organiser powers. Nowadays the development of globalisation processes unambiguously shows that human factors and the knowledge based on it may become the future key factors to development. We live in a world where knowledge, human creativity and the ability to pro-cess infinite information are also one of the prime movers of development.

This study aims to analyse how Hungarian micro-regions can be classified according to the position of the creative class. The starting question is whether the micro-regions as regional units are suitable to examine the spatial position of the creative class. Further basic questions are what sort of connection there is between the position of the creative class and income formation and whether the creative class is really concentrated in urban areas.

In the analysis of the Hungarian micro-regions I take Richard Florida's study dealing with the creative class as a starting point. I examine the database and its indexes developed for Hungarian micro-regions with multivariable statistical analysis. 